\title{
PENGARUH MOTIVASI, KUALITAS LAYANAN, DAN KEPUASAN WISATAWAN TERHADAP IMAGE DAERAH TUJUAN WISATA
}

\author{
Martaleni \\ martaleni@yahoo.com \\ Fakultas Ekonomi dan Bisnis - Universitas Gajayana Malang
}

\begin{abstract}
The rapid growth of tourism industry has to incourage the development in local region, increased national incomes, improve people's welfare and prosperity; and this can grow the national patriotism and cultural values. Therefore, the management and enhancement of the image of Tourist Destination Areas (TDA) is a step that should get continously and serious attention. The aimed of this study is to examine and analyze either direct or indirect effects of values of tourist motivation, service quality and tourist satisfaction on Tourist Destination Area (TDA). Data that we need in this research, we collected from a sample consist of 200 respondens. The population are all of the tourists who came from out of Malang Raya and who wanted to visit TDA in MalangRaya. Data were analyzed by using a descriptive and inferential statistical methods. The findings of this research explained that the service quality and tourist motivation increased, then it will be able to increase the value of tourist satisfaction in the tourist destination areas. On the other hand, the tourism service quality could improve the image of tourism destination area directly. Further, through the tourist satisfaction, and increase in the value of tourist motivation and service quality can indirectly improve the tourist image of the DTW.
\end{abstract}

Keywords: tourism, motivation, service quality, satisfaction, image

\begin{abstract}
ABSTRAK
Pertumbuhan industri pariwisata yang semakin pesat dapat mendorong pembangunan daerah, meningkatkan devisa negara, meningkatkan kesejahteraan dan kemakmuran rakyat serta dapat menambah rasa cinta tanah air, bangsa dan nilai-nilai budaya. Oleh karena itu, pengelolaan dan penguatan image suatu Daerah Tujuan Wisata (DTW) merupakan langkah yang harus mendapatkan perhatian yang serius secara terus menerus. Tujuan dari penelitian ini adalah menguji dan menganalisis pengaruh nilai motivasi wisatawan, kualitas layanan dan kepuasan wisatawan secara langsung dan tidak langsung terhadap image DTW. Data yang dibutuhkan untuk penelitian ini diperoleh dari sampel sebanyak 200 responden. Adapun populasi terdiri dari seluruh wisatawan yang berasal dari luar Malang Raya dan bertujuan untuk berwisata ke DTW Malang Raya. Data dianalisis menggunakan metode statistik deskriptif dan inferensial. Temuan penelitian ini menjelaskan bahwa semakin meningkat nilai motivasi wisatawan dan kualitas layanan wisata akan dapat meningkatkan nilai kepuasan wisatawan terhadap Daerah Tujuan Wisata. Di samping itu meningkatnya kualitas layanan wisata dapat secara langsung meningkatkan image wisatawan terhadap DTW. Selanjutnya melalui kepuasan wisatawan, peningkatan nilai motivasi wisatawan dan kualitas layanan secara tidak langsung dapat meningkatkan image wisatawan terhadap DTW.
\end{abstract}

Keywords: pariwisata, motivasi, kualitas layanan, kepuasan, image

\section{PENDAHULUAN}

Pertumbuahan industri pariwisata yang semakin pesat dapat mendorong pembangunan daerah, meningkatkan devisa negara, yang selanjutnya dapat meningkatkan kesejahteraan dan kemakmuran rakyat serta dapat menambah rasa cinta tanah air, bangsa dan nilai-nilai budaya (Fandeli, 2008; Martaleni, 2010). Menurut World tourism Organization (2014), penerimaan pariwisata internasional mencapai 1159 miliar dolar pada tahun 2013, naik dari 
1097 miliar dollar pada tahun 2012. Selain itu, jumlah kedatangan wisatawan internasional ke depan diperkirakan trendnya meningkat rata-rata sebesar 3,3\% per tahun, dan mulai tahun 2010 sampai tahun 2030 sekitar 43 juta lebih kedatangan wisatawan internasional setiap tahun dan sebesar 1,8 miliar kedatangan wisata pada tahun 2030.

Sementara itu, sektor pariwisata di Indonesia terus memberikan peran dalam meningkatkan devisa negara melalui peningkatan jumlah kunjungan wisata dan penyerapan tenaga kerja. Peningkatan tersebut sebagaimana tercermin dalam laporan kinerja kementerian pariwisata dan ekonomi kreatif pada tahun 2014, dimana kunjungan wisatawan mancanegara (wisman) pada tahun 2013 sebanyak 8,80 juta. Dibanding dengan jumlah kunjungan wisman pada tahun 2012, yaitu sebanyak 8,04 juta maka jumlah kunjungan wisman pada tahun 2013 dapat dikatakan mengalami pertumbuhan sebesar 9.42\%. Adapun jumlah kunjungan wisatawan nusantara (wisnus) pada tahun 2013 mencapai 248 juta perjalanan atau naik sebesar $1,10 \%$ dibanding jumlah kunjungan tahun 2012 yaitu sebanyak 245,29 juta perjalanan. Sementara itu dampak terbesar sektor pariwisata terhadap perekonomian adalah dalam hal penyerapan tenaga kerja. Pada tahun 2013 terdapat sekitar 10.18 juta orang bekerja pada sektor-sektor pariwisata, yang berarti bahwa terjadi penyerapan tenaga kerja sebanyak $8.89 \%$ terhadap kesempatan kerja nasional.

Pengembangan dan peningkatan kepariwisataan di Indonesia mendapat dukungan sangat kuat dari pemerintah Repubik Indonesia. Hal ini terlihat dengan dikeluarkannya Undang-Undang Republik Indonesia Nomor 10 Tahun 2009 tentang Kepariwisataan, dimana untuk mewujudkan harapan dari undang-undang tersebut diamanatkan bahwa setiap kepala daerah dituntut untuk mendukungnya. Martaleni (2011) menjelaskan bahwa pengembangan pariwisata, bukanlah hanya tanggung jawab pemerintah pusat, melainkan juga merupa- kan tanggung jawab bersama antara pemerintah pusat dan pemerintah daerah. Sebagai pemegang kekuasaan dan kewenangan, tentunya pemerintah daerah lebih menguasai dan memahami tentang potensi daerahnya, sehingga dapat lebih tepat dalam menentukan obyek wisata yang perlu dikembangkan.

Malang Raya, yang terdiri atas Kota Malang, Kabupaten Malang, dan Kota Batu merupakan bagian integral dari negara Republik Indonesia. Dengan demikian Pemerintah Daerah di masing-masing daerah tersebut juga mempunyai kewajiban untuk meningkatkan peran pariwisatanya dalam rangka mendukung roda pembangunan di daerah Malang Raya khususnya, dan di negara Indonesia pada umumnya. Dari segi geografis, Malang Raya mempunyai potensi yang memungkinkan pertumbuhan dan pengembangan wilayahnya berbasis pada pariwisata. Salah satu potensi yang dapat mendukung adalah kondisi alam sekitarnya, dimana Kota Malang sebagai kota pendidikan, Kabupaten Malang dengan beragam pantainya dan kota Batu dengan iklimnya yang dingin dan sejuk (Martaleni, 2011).

Berdasarkan uraian tersebut, tampak bahwa sumberdaya alam Malang Raya sangat menunjang untuk pengembangan pariwisata. Pengembangan daya tarik wisata dapat dilakukan melalui berbagai hal, diantaranya melalui peningkatan kualitas layanan secara terus menerus pada objekobjek wisata, perbaikan sarana pendukung, dan sebagainya, sehingga hal ini diharapkan akan dapat memuaskan wisatawan. Kepuasan wisatawan merupakan tujuan dari pengelola wisata dan pemerintah terkait serta merupakan topik penting dalam manajemen pariwisata, karena kepuasan wisatawan terhadap Daerah Tujuan wisata (DTW) dapat berpengaruh pada image dan loyalitas wisatawan (Labato, 2006; Andaleeb dan Conway, 2006; Wu, 2007; Tsung, 2009; Yuksel et al, 2010). Selain itu, karena image merupakan kunci dalam membangun posisi suatu daerah tujuan wisata, sehingga 
menciptakan image positif daerah tujuan wisata harus terus diupayakan (Faulantet al, 2008; Martaleni, 2010).

Dalam rangka pengembangan strategi pemasaran, mengukur image daerah tujuan wisata dan mengidentifikasi seberapa puas wisatawan dengan kualitas layanan wisata yang ditawarkan merupakan keharusan yang tidak dapat diabaikan. Dengan demikian akan memudahkan dalam melakukan promosi tentang daerah tujuan wisata (Ibrahim dan Gill, 2005; Chi dan Qu, 2008; Brunner, Stocklin, dan Opwis, 2008; Park, dan Yoon, 2009; Chen dan Chenet al,2010). Bila mengkaji tentang kualitas layanan wisata dan image tidak terlepas dari peran motivasi wisatawan terhadap kepuasan wisatawan, karena tingkat kepuasan wisatawan terhadap apa yang dirasakan saat berada di daerah tujuan wisata dapat di pengaruhi oleh apa yang menjadi motivasinya berwisata sehingga akan berimplikasi pada strategi pemasaran pariwisata (Yoon dan Uysal, 2005; Coreria da Valle, 2007; Park, dan Yoon, 2009; Mohammad dan Som, 2010; Devesaet al, 2010).

Berdasarkan uraian dari latar belakang diatas, maka permasalahan dalam penelitian ini dapat dirumuskan sebagai berikut: Apakah motivasi wisatawan, kualitas layanan wisata dan kepuasan wisatawan secara langsung dan tidak langsung berpengaruh positif terhadap image DTW, sedangkan, tujuan dari penelitian ini adalah untuk menguji dan menganalisis pengaruh nilai motivasi wisatawan, kualitas layanan wisata dan kepuasan wisatawan secara langsung dan tidak langsung terhadap image DTW.

\section{TINJAUAN TEORETIS \\ Motivasi}

Pada umumnya setiap unit bisnis baik yang bergerak di bidang manufacture maupun jasa memiliki perencanaan strategis yang dapat mengidentifikasi peluang, ancaman dan arah di masa yang akan datang. Bila sebuah unit bisnis mengembangkan berbagai strategi untuk mencapai perencanaan strategis, maka nilai dari unit bisnis tersebut dapat dimaksimalkan. Salah satu strategi yang dapat dikembangkan oleh sebuah unit bisnis adalah strategi pemasaran dengan meningkatkan nilai terhantar pada konsumen. Untuk itu, diperlukan pemahaman tentang motivasi seseorang dalam keputusannya membeli suatu produk. Lamb et al, (2005) menyatakan dengan mempelajari motivasi, para pelaku pasar dapat menganalisis faktorfaktor utama yang mempengaruhi seseorang dalam membeli atau tidak membeli suatu produk.

Motivasi merupakan kebutuhan yang memadai yang dapat mendorong seseorang untuk bertindak. Seseorang memiliki banyak kebutuhan pada waktu tertentu, dan beberapa kebutuhan bersifat biogenis, kebutuhan tersebut muncul dari tekanan biologis seperti lapar, haus, tidak nyaman. Kebutuhan yang lain bersifat psikogenis, yang muncul dari tekanan psikologis seperti kebutuhan akan pengakuan, penghargaan atau rasa bagian dari suatu kelompok atau komunitas, sehingga kebutuhan akan menjadi motif jika ia didorong hingga mencapai level intensitas yang memadai (Kotler dan Keller, 2012).

Lamb et al. (2005) menyatakan bahwa motivasi merupakan kekuatan pendorong yang menyebabkan seseorang melakukan tindakan untuk memenuhi kebutuhannya. Abrahan Maslow, seorang psikolog, mengembangkan teori hirarki kebutuhan (hierarcy of needs) dengan memperingkat kebutuhan seseorang menjadi lima tingkatan: physiological needs, safety needs, social needs, esteem needs dan self-actualization needs (Kotler dan Keller, 2012).

Berdasarkan uraian dari motivasi dan tingkatan kebutuhan seseorang, dapat dijelaskan bahwa seorang akan terdorong melakukan pembelian pada suatu produk bila produk tersebut dapat memenuhi kebutuhannya. Dengan demikian pelaku pemasaran dapat menawarkan dan mengiklankan produknya berdasarkan tingkatan kebutuhan seorang wisatawan. Kebutuhan paling dasar seseorang adalah fisiologis 
(physiological needs) yaitu kebutuhan akan makanan, minuman dan tempat tinggal. Karena hal-hal itu sangat penting untuk kelangsungan hidup, maka kebutuhan itu harus terlebih dahulu dipenuhi. Terkait dengan produk wisata, secara umum merupakan kebutuhan sekunder atau kebutuhan kedua. Namun tujuan utama seseorang berwisata adalah untuk memenuhi kebutuhan relaksasi, kebersamaan dengan kelurga. Untuk itu, iklan yang menampilkan ke bersamaan dengan keluarga pada alam yang indah, menarik dan sejuk merupakan suatu contoh pesan iklan untuk menarik wisatawan dalam memenuhi kebutuhan sekunder atau social need.

\section{Kualitas Layanan}

Dewasa ini produk jasa sangat mendominasi kehidupan masyarakat dan perkembangannya yang sedemikain pesat seiring dengan perkembangan sektor-sektor lainnya (Tjiptona dan Chandra, 2011). Kualitas jasa atau kualitas layanan (service quality) berkontribusi signifikan bagi penciptaan diferensiasi, positioning, dan strategi bersaing setiap organisasi pemasaran, baik perusahaan manufaktur maupun penyedia jasa. Sayangnya, minat dan perhatian pada pengukuran kualitas jasa baru berkembang sejak dekade 1980-an (Tjiptona dan Chandra, 2011). Lebih lanjut dikatakan bahwa jasa adalah mencakup semua aktivitas ekonomi yang outputnya bukanlah produk atau kostruksi fisik, yang secara umum konsumsi dan produksinya dilakukan pada waktu yang sama, dan nilai tambah yang diberikan dalam bentuk yang secara prinsip intangible bagi pembeli utamanya.

Kotler dan Keller (2012) membedakan lima kategori tawaran perusahan kepada pasar, sebagai berikut: a) Pure tangible good, b) Tangible good with accopanying service, c) Hybrid, d). Mayor service with accompanying minor goods and services, dan e) Pure service. Dari kategori jasa tersebut dapat dijelaskan bahwa penawaran jasa kepada konsumen dapat dilakukan berupa murni barang tanpa disertai jasa, barang disertai jasa, kombinasi barang dan jasa hampir seimbang, jasa utama yang disertai barang sebagai tambahan dan murni jasa.

Pembahasan tentang kualitas jasa merupakan bagian yang sangat kompleks, karena penilaian kualitas jasa berbeda dengan penilaian terhadap kualitas produk, terutama karena sifatnya yang tidak nyata (intangible) dan produksi serta konsumsi berjalan secara simultan. Disamping perbedaan karakteristik ini, dalam penilaian kualitas jasa wisatawan terlibat secara langsung serta ikut di dalam proses jasa. Dengan demikian penilaiannya tergantung pada bagaimana tanggapan wisatawan terhadap jasa yang dikonsumsi atau yang dirasakannya. Melalui penelitian pasar, setiap penyedia jasa harus dapat menentukan apa yang menjadi kebutuhan atau keinginan utama wisatawan. Penilaian wisatawan terhadap kualitas jasa berbeda dengan penilaian terhadap produk berwujud.

Dalam konteks penilaian kualitas produk maupun jasa dapat dinyatakan bahwa harapan wisatawan memiliki peranan yang besar sebagai standar perbandingan dalam evaluasi kualitas maupun kepuasan (Kotler dan Keller, 2012). Selanjutnya, dinyatakan bahwa yang dimaksud dengan kepuasan wisatawan terhadap suatu jasa adalah perbandingan antara persepsi wisatawan terhadap jasa yang diterima dan harapannya sebelum menggunakan jasa tersebut. Apabila harapannya terlampaui, berarti jasa tersebut telah memberikan suatu kualitas yang luar biasa dan juga akan menimbulkan kepuasan yang sangat tinggi (very satisfy). Sebaliknya, apabila harapannya itu tidak tercapai, maka diartikan kualitas jasa tersebut tidak memenuhi apa yang diinginkannya atau perusahaan tersebut gagal melayani wisatawannya. Apabila harapannya sama dengan apa yang dia peroleh, berarti wisatawan itu puas (satisfy)

\section{Kepuasan}

Mengkaji dan memahami tingkat kepuasan pelanggan telah menjadi konsep sentral dalam sebuah bisnis dan manajemen 
suatu organisasi. Kepuasan pelanggan telah memberikan manfaat-manfaat penting dalam bisnis yang meliputi keterkaitan positif dengan loyalitas pelanggan, membangun sebuah image organisasi, meningkatkan toleransi harga, dan sebagainya. Definisi kepuasan yang terdapat dalam berbagai literatur cukup beragam, Kotler dan Keller (2012) mendefinisikan kepuasan sebagai perasaan suka/tidak suka seseorang terhadap suatu produk setelah membandingkan prestasi produk tersebut dengan harapannya.

Kotler dan Keller (2012) mengidentifikasi empat metode untuk mengukur kepuasan pelanggan. Pertama, sistem keluhan pelanggan dan saran, dimana setiap organisasi yang berorientasi pada pelanggan (customer-oriented) perlu menyediakan kesempatan dan akses yang mudah dan nyaman bagi para pelanggan guna menyampaikan saran, kritik, pendapat, dan keluhan mereka. Kedua, Ghost shopping atau Mystery shopping, merupakan salah satu cara untuk memperoleh gambaran mengenai kepuasan pelanggan dengan mempekerjakan beberapa orang ghost shopping untuk berperan atau berpura-pura sebagai pelanggan potensial produk perusahaan atau pesaing. Mereka diminta berinteraksi dengan staf penyedia jasa dan menggunakan produk/jasa perusahaan. Ketiga, Lost customer analysis, yaitu menghubungi para pelanggan yang telah berhenti membeli atau yang telah pindah pemasok agar dapat memahami mengapa hal itu terjadi dan supaya dapat mengambil kebijakan perbaikan selanjutnya. Keempat Survei kepuasan pelanggan, yaitu riset kepuasan pelanggan dilakukan dengan menggunakan metode survei, baik survei melalui pos, telepon, e-mail, websits, maupun wawancara langsung.

\section{Image}

Pitana (2009) menyatakan bahwa image merupakan ide atau kepercayaan yang dimiliki wisatawan tentang produk atau pelayanan yang mereka beli atau mereka akan beli. Image destinasi tidak selalu berdasarkan pengalaman atau fakta, tetapi dapat dibentuk sedemikian rupa sehingga menjadi faktor motivasi atau pendorong yang kuat untuk melakukan perjalanan wisata ke destinasi tersebut. Ini memberi arti bahwa kepercayaan, ide, serta impresi seseorang sangat besar pengaruhnya terhadap sikap dan perilaku serta respon yang mungkin akan dilakukannya.

Suatu perusahaan akan terlihat melalui image-nya baik yang positif atau negatif. Image yang positif akan memberikan arti yang baik terhadap produk perusahaan tersebut dan lebih lanjut dapat meningkatkan jumlah penjualan. Sebaliknya penjualan suatu produk akan mengalami penurunan jika imagenya dipandang negatif oleh masyarakat. Dalam industri pariwisata image dapat diukur dari dua komponen: pertama berdasarkan atribut berbasis holistik dan kedua berbasis atribut fungsional yang lebih abstrak. Lebih lanjut Hankinson (2005) berpendapat bahwa mengukur image daerah tujuan wisata dapat dilakukan melalui dimensi keseluruhan atraksi pada daerah tujuan wisata, fungsionalitas dan suasana. Dari uraian tentang pengukuran image tersebut dapat dipahami bahwa dalam mengevaluasi image seseorang terhadap suatu objek dapat dilihat dari aspek kognitif dan afektif. Komponen kognitif merupakan kepercayaan dan pengetahuan mengenai objek atau orang, sedangkan afektif mewakili perasaan terhadap objek (sedih, senang, dan sebagainya).

Menurut Yoeti (2006), salah satu hal yang menentukan pengembangan kepariwisataan adalah pemasaran kepariwisataan. Lebih jauh Yoeti (2006) menekankan bahwa istilah produk wisata atau produk pariwisata kurang tepat, seharusnya digunakan istilah produk industri pariwisata, karena hanya industri yang menghasilkan produk, sedangkan wisata dan pariwisata tidak. Memasarkan produk industri pariwisata jauh lebih kompleks sifatnya dibandingkan dengan memasarkan produk yang lain. Produk industri pariwisata secara umum 
telah diakui sebagai produk jasa (Vellas dan Becherel, 2008).

\section{Penelitian Sebelumnya dan Pengembang- an Hipotesis}

Melakukan kajian tentang motivasi wisatawan mengunjungi suatu DTW perlu mendapatkan perhatian yang serius dari pengelola DTW atau pemerintah terkait. Selain motivasi seseorang melakukan wisata merupakan suatu segmen yang dapat mempengaruhi efektifitas pengembangan wisata (Parkdan Yoon, 2009) juga dapat mempengaruhi kepuasan yang dirasakan oleh wisatawan terhadap DTW baik secara langsung maupun secara tidak langsung. Kajian tentang pengaruh motivasi dan kepuasan wisatawan, belum begitu banyak menarik perhatian peneliti sebelumnya, namum Yoon dan Uysal (2005) telah menguji dampak motivasi dan kepuasan pada loyalitas wisatawan dan temuan penelitiannya mengungkapkan bahwa motivasi berpengaruh tidak signifikan pada kepuasan wisatawan. Berbeda dengan Devesaet al. (2010), yang melakukan penelitian di Spanyol dengan tujuan menginvestigasi hubungan antara motivasi dan kepuasan wisatawan, menyimpulkan bahwa motivasi berpengaruh positif pada kepuasan wisatawan. Berdasarkan uraian tersebut diatas, hipotesis penelitian yang akan diuji adalah sebagai berikut:

$\mathrm{H}_{1}$ : Semakin tinggi motivasi wisatawan untuk berwisata, semakin meningkat kepuasan wisatawan.

Selain dipengaruhi oleh motivasi wisatawan juga dapat dipengaruhi oleh tingkat kualitas dari berbagai bentuk layanan yang diberikan pada wisatawan mulai wisatawan memasuki lingkungan DTW sampai wisatawan kembali meninggalkan DTW, tingkat kepuasan wisatawan dapat dipengaruhi oleh banyak hal. Banyak kajian telah dilakukan dengan tujuan menguji pengaruh kualitas layanan terhadap kepuasan konsumen, seperti yang dilakukan oleh Labato (2006), Andaleeb dan
Conway (2006), Wu (2007), Tsung (2009), Yuksel Et al, (2010), Martaleni, (2011). Secara umum hasil kajian tersebut menunjukkan bahwa semakin meningkat kualitas layanan akan semakin meningkatkan kepuasan wisatawan. Berbeda dengan hasil kajian Correia dan Valle (2007), Hutchinson atal, (2009) dan Chen dan Tsai (2007), yang juga menguji pengaruh kualitas layanan terhadap kepuasan, mengungkapkan bahwa pelayanan yang diberikan tidak berpengaruh positif terhadap kepuasan konsumen atau semakin meningkat kualitas layanan tidak dapat meningkatkan kepuasan konsumen. Dengan demikian dapat dirumuskan sebuah hipotesis sebagai berikut: $\mathrm{H}_{2}$ : Semakin tinggi nilai kualitas layanan wisata, semakin meningkatkan kepuasan wisatawaan.

Perbaikan dan pengembangan kualitas layanan wisata secara terus menerus merupakan suatu keharusan yang tidak dapat ditawar oleh pegelola wisata dan pemerintah terkait, bila ingin memenangkan persaingan di pasar yang semakin kompetitif. Peningkatan kualitas layanan akan berdampak pada image positif wisatawan baik secara langsung maupun tidak langsung dan dapat dijadikan sebagai kunci dalam membangun positioning DTW (Faulantet al, 2008; Martaleni, 2010). Penelitian yang bertujuan menguji pengaruh kualitas layanan terhadap image, telah dilakukan oleh Hankinson (2005), Kandampully dan HsinHui Hu (2007), Chen dan Chen (2010) dan secara umum mengungkapkan bahwa, semakin meningkat kualitas layanan yang diberikan oleh DTW dan hotel akan semakin meningkatkan image konsumen terhadap DTW dan hotel.

$\mathrm{H}_{3}$ : Semakin tinggi kualitas layanan wisata, semakin meningkat image wisatawan.

$\mathrm{H}_{4}$ : Tingginya motivasi wisatawan dan kualitas layanan wisata secara tidak langsung akan meningkatkan image wisatawan melalui kepuasan. 


\section{Rerangka Konseptual}

Berdasarkan pada kajian teoretis dan empiris, dapat disusun rerangka konseptual sebagaimana terlihat pada Gambar 1. Dalam penelitian ini digunakan empat variabel, yaitu motivasi, kualitas layanan, kepuasan dan image. Selanjutnya akan diteliti tentang pengaruh antar variabel, dalam hal ini pengaruh motivasi dan kualitas layanan secara langsung terhadap kepuasan, pengaruh tidak langsung dari motivasi dan kualitas layanan terhadap image melalui kepuasan, dan pengaruh langsung kualitas layanan terhadap image.

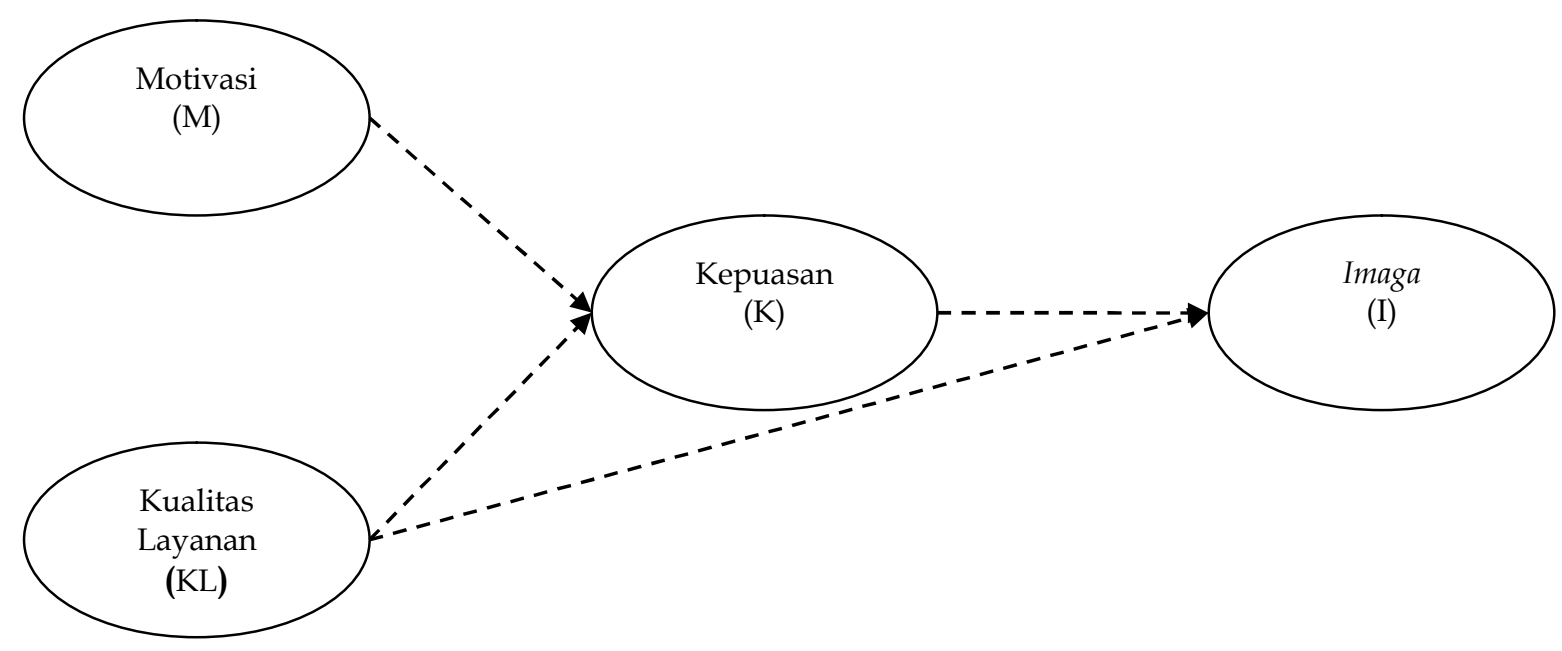

\section{Gambar 1 \\ Kerangka Konseptual}

\section{METODE PENELITIAN}

Daerah Tujuan Wisata (DTW) Malang Raya merupakan objek kajian dari penelitian ini dengan populasi adalah seluruh wisatawan nusantara yang berasal dari luar Malang Raya dan bertujuan untuk berwisata (bukan bertujuan untuk bisnis) di DTW Malang Raya. Pengambilan sampel dilakukan secara purposive sampling. Penentuan besarnya sampel mengacu pada pendapat para pakar

Alat analisis data yang digunakan dalam penelitian ini adalah Structural Equation Modeling berbasis Component (CBSEM) yang umum dikenal dengan Partial Least Square (PLS). Dalam penelitian ini terdapat 16 manifest (indikator) formatif, sehingga besarnya sampel yang diambil sebagaimana pendapat Solimun (2008) yaitu $10 \times 16$ $=160$. Sementara itu, untuk mengantisipasi terjadinya data bias, maka banyaknya sampel ditambah $25 \%$ dari 160 , sehingga total sampel yang digunakan adalah sebesar 200.

Jenis data dalam penelitian ini merupakan data primer yang dikumpulkan dengan menggunakan kuesioner sebagai instrumen penelitian. Jawaban-jawaban dari responden dikuantitatifkan serta diukur dengan skala Likert lima kategori yang berkisar dari "sangat tidak setuju" sampai dengan "sangat setuju". Selain itu, variabel yang akan dianalisis dalam penelitian ini diklasifikasikan menjadi dua kelompok, yakni variabel independen dan variabel dependen. Variabel independen dikelompokkan menjadi tiga variabel yaitu: (a) Motivasi wisatawan, yang diukur dengan 4 (empat) indikator, yaitu: beristirahat/relaksasi, mencari ketenangan/ keheningan, kebersamaan dengan keluarga dan kontak dengan alam. (b) Kualitas layanan wisata, yang diukur dengan 3 (tiga) indikator, yaitu: daya tarik objek wisata, kondisi sarana pendukung dan empati 
(emphaty), (c) Kepuasan wisatawan yang diukur dengan perbandingan antara harapan dan kenyataan pada masing-masing indikator kualitas layanan wisata. Variabel dependen dalam penelitian ada Image DTW yang diukur dengan 3 (tiga) indikator, yaitu: iklim, biaya wisata, kondisi alam.

Penyebaran kuesioner dilakukan pada bulan Februari hingga Agustus 2011 bertempat di tempat-tempat rekreasi yang berada di wilayah Kota Malang, Kabupaten Malang dan Kota Batu. Beberapa tempat rekreasi yang digunakan untuk penyebaran kuesioner di Kota Malang antara lain pusat belanja Matos, MX, Pasar Besar dan pusat oleh-oleh Sanan. Sementara itu, untuk penyebaran kuesioner di Kabupaten Malang antara lain di Taman Rekreasi Sengkaling, Taman Rekreasi Wendit dan Taman Rekreasi Pantai Balekambang. Di Kota Batu antara lain Taman Rekreasi BNS, Taman Rekreasi Jatim Park, Taman Rekreasi Selecta. Kuesioner disebarkan kepada para wisatawan baik yang sedang berada di dalam tempat rekreasi maupun yang sedang berada di luar tempat rekreasi (sedang beristirahat). Penentuan responden dilakukan secara acak dan dalam waktu yang berbeda.

\section{ANALISIS DAN PEMBAHASAN}

Tehnik pengumpuan data dilakukan melalui penyebaran kuesioner kepada sebanyak 200 orang responden dan dilakukan langsung bertemu dengan responden, dimana setiap responden diminta untuk mengisi satu exemplar kuesioner. Dengan demikian jumlah kuesioner yang terkumpul juga sebanyak 200. Adapun banyaknya responden di masing-masing kota/kabupaten adalah: Kota Malang sebanyak 60 orang, Kabupaten Malang sebanyak 50 orang dan Kota Batu sebanyak 90 orang. Karakteristik demografi responden selengkapnya dapat dilihat dalam Tabel 1 . Karakteristik demografi meliputi jenis kelamin, umur, pendidikan, pekerjaan dan besarnya dana yang dibelanjakan selama berwisata.
Berdasarkan Tabel 1 dapat dijelaskan bahwa sebaran jenis kelamin responden terdiri atas $54 \%$ responden laki-laki dan $46 \%$ responden wanita. Usia responden berkisar antara 15 tahun hingga lebih dari 51 tahun dengan persentase terdiri atas $57,5 \%$ responden berusia antara 15 dan 20 tahun, $18 \%$ responden berusia antara 21 dan 30 tahun, $11 \%$ responden berusia antara 31 dan 34 tahun, 11,5\% responden berusia antara 35 dan 50 tahun dan $2 \%$ responden berusia lebih dari 51 tahun. Persentase tertinggi dari tingkat pendidikan responden adalah 57,5\% berpendidikan SLTA, 21\% responden berpendidikan SLTP dan 0,5\% responden berpendidikan Pascasarjana. Ditinjau dari sisi pekerjaan, sebanyak $63 \%$ responden sebagai mahasiswa/pelajar, sebanyak $12,5 \%$ bekerja sebagai PNS/BUMN, pegawai swasta, pengusaha/berwiraswata dan sebanyak $7 \%$ bekerja dalam bidang pekerjaan lainnya. Besar dana yang dibelanjakan selama berwisata di Malang Raya, berkisar antara kurang dari Rp. 500.000,- dan lebih dari Rp. 2.000.000,-Sebanyak $44,05 \%$ responden mengatakan membelanjakan dana kurang dari $\mathrm{Rp}$. 500.000,- Sebanyak 32\% responden membelanjakan dana antara Rp. 500.000,- dan Rp. $1.000 .000,-$, sebanyak $15,05 \%$ responden membelanjakan dana antara Rp. 1.000.000,dan Rp. 2.000.0000,-, dan sebanyak 8\% responden membelanjakan dana lebih dari Rp. 2.000.000,-. Berdasarkan data tersebut dapat dikatakan bahwa responden yang digunakan merupakan sampel yang dapat merepresentasikan populasi baik ditinjau dari jenis kelamin, usia, pekerjaan, dan besarnya dana yang dibelanjakan.

\section{Variabel Motivasi Wisatawan}

Variabel motivasi wisatawan diukur dengan menggunakan empat indikator yaitu indikator beristirahat/relaksasi, mencari ketenangan, kebersamaan dengan keluarga, dan kontak dengan alam. Masing-masing indikator diukur berdasarkan jawaban responden atas pertanyaan yang diajukan dalam kuesioner. 
Tabel 1

Karakteristik Demografi Responden

\begin{tabular}{|c|c|c|c|}
\hline \multicolumn{2}{|c|}{ Karakteristik } & \multirow{2}{*}{$\begin{array}{c}\begin{array}{c}\text { Frekuensi } \\
\text { (orang) }\end{array} \\
108\end{array}$} & \multirow{2}{*}{$\begin{array}{l}\% \\
54\end{array}$} \\
\hline Jenis Kelamin & Laki-laki & & \\
\hline & Perempuan & 92 & 46 \\
\hline & Total & 200 & 100 \\
\hline \multirow[t]{6}{*}{ Usia } & $15-20$ th & 115 & 57,5 \\
\hline & $21-30$ th & 36 & 18 \\
\hline & $31-34$ th & 22 & 11 \\
\hline & $35-50$ th & 23 & 11,5 \\
\hline & $>51$ th & 4 & 2 \\
\hline & Total & 200 & 100 \\
\hline \multirow[t]{7}{*}{ Pendidikan Formal } & SD & 9 & 4,5 \\
\hline & SLTP & 42 & 21 \\
\hline & SLTA & 115 & 57,5 \\
\hline & Diploma & 6 & 3 \\
\hline & Sarjana & 27 & 13,5 \\
\hline & Pascasarjana & 1 & 0,5 \\
\hline & Total & 200 & 100 \\
\hline \multirow[t]{7}{*}{ Pekerjaan } & PNS/ BUMN & 16 & 20,69 \\
\hline & Pegawai Swasta & 25 & 14,66 \\
\hline & Pengusaha/Wiraswasta & 18 & 12,50 \\
\hline & TNI & 1 & 0,5 \\
\hline & Mahasiswa/Pelajar & 126 & 63 \\
\hline & Lainya & 14 & 7 \\
\hline & Total & 200 & 100 \\
\hline \multirow{5}{*}{$\begin{array}{c}\text { Besar dana yang dibelanjakan } \\
\text { selama kunjungan }\end{array}$} & Kurang dari Rp. 500.000,- & 89 & 44,05 \\
\hline & Rp. 500.000,- - Rp. 1.000.000,- & 64 & 32 \\
\hline & Rp. 1.000.000,-- Rp. 2.000.000,- & 31 & 15,05 \\
\hline & Lebih dari Rp. 2.000.000,- & 16 & 8 \\
\hline & Total & 200 & 100 \\
\hline
\end{tabular}

Pada setiap pertanyaan disediakan 5 pilihan jawaban, yaitu sangat tidak setuju yang diberi bobot 1, tidak setuju diberi bobot 2, netral diberi bobot 3, setuju diberi bobot 4 , dan sangat setuju diberi bobot 5 . Persentase dari jumlah responden yang memberikan jawaban atas pertanyaan tersebut dikalikan dengan masing-masing bobot dan menghasikan nilai rata-rata setiap indikator variabel sebagaimana tercantum pada kolom kedua dalam Tabel 2 . Berdasarkan Tabel 2 tersebut tampak bahwa indikator keempat yaitu kontak dengan alam memperoleh rata-rata tertinggi, disusul kebersamaan dengan keluarga, beristirahat/relaksasi dan mencari ketenangan merupakan indikator yang paling lemah. Hal tersebut menunjukkan bahwa motivasi utama wisatawan berkunjung ke DTW Malang Raya adalah untuk dapat menikmati alam bersama keluarga. Selanjutnya nilai rata-rata keseluruhan sebesar 4,03 dapat diinterpretasikan bahwa motivasi wisatawan memiliki nilai yang tinggi dalam menentukan image sebuah DTW. 
Tabel 2

Nilai Rata-rata Variabel

\begin{tabular}{llrc}
\hline \hline \multicolumn{1}{c}{ Variabel } & \multicolumn{1}{c}{ Indikator } & $\begin{array}{c}\text { Rata- } \\
\text { rata }\end{array}$ & $\begin{array}{c}\text { Rata-rata } \\
\text { keseluruhan }\end{array}$ \\
\hline \multirow{3}{*}{ Motivasi Wisatawan } & Beristirahat/relaksasi & 4,06 & \\
& Mencari ketenangan & 3,87 & \multirow{2}{*}{4,03} \\
& Kebersamaan dengan keluarga & 4,09 & \\
& Kontak dengan alam & 4,12 & \\
Kualitas Layanan & Daya Tarik Obyek Wisata & 3,94 & \multirow{2}{*}{3,73} \\
& Kondisi Sarana Pendukung & 3,87 & \\
& Empati & 3,55 & \\
Kepuasan Wisatawan & Kepuasan terhadap daya tarik obyek & & \\
& wisata & 3,80 & \multirow{2}{*}{3,70} \\
& Kepuasan terhadap sarana pendukung & 3,79 & \\
& Kepuasan terhadap empati & 3,52 & \\
\hline \multirow{3}{*}{ Image DTW } & Iklim & 4,19 & \multirow{2}{*}{3,05} \\
& Biaya wisata & 4,24 & \\
\hline
\end{tabular}

\section{Variabel Kualitas Layanan}

Variabel Kualitas Layanan diukur dengan menggunakan tiga indikator yaitu daya tarik objek wisata, kondisi sarana pendukung, dan empati. Masing-masing indikator diukur berdasarkan jawaban responden atas pertanyaan yang diajukan dalam kuesioner. Pada setiap pertanyaan disediakan 5 pilihan jawaban dan masingmasing jawaban diberi bobot sebagaimana di atas. Nilai rata-rata setiap indikator variabel sebagaimana tercantum pada kolom kedua dalam Tabel 2. Berdasarkan Tabel 2 tersebut, tampak bahwa indikator pertama yaitu daya tarik obyek wisata berada pada level paling tinggi dengan ratarata sebesar 3,94, kemudian disusul kondisi sarana pendukung dan empati. Hal ini dapat di- maknai bahwa wisatawan yang berkunjung ke DTW lebih memperhatikan daya tarik obyek wisata yang ditawarkan oleh DTW seperti tersedianya berbagai macam objek wisata. Selanjutnya wisatawan akan mem- perhatikan kondisi sarana pendukung yang tersedia dan tingkat empati masyarakat atau petugas wisata dalam melayani dan memperlakukan wisatawan saat berada di DTW Malang Raya.

\section{Variabel Kepuasan Wisatawan}

Variabel kepuasan wisatawan diukur dengan menggunakan tiga indikator yaitu perbandingan antara harapan dan kenyataan pada keseluruhan daya tarik objek wisata, perbandingan antara harapan dan kenyataan pada semua sarana pendukung yang disediakan dan perbandingan antara harapan dan kenyataan dari perhatian yang diberikan oleh petugas dan penduduk sekitar. Masing-masing indikator diukur berdasarkan jawaban responden atas pertanyaan yang diajukan dalam kuesioner. Pada setiap pertanyaan disediakan 5 pilihan jawaban dan masing-masing jawaban diberi bobot sebagaimana di atas. Nilai rata-rata setiap indikator variabel sebagaimana tercantum pada kolom kedua dalam Tabel 2 . Berdasarkan Tabel 2 tersebut, dapat dijelaskan bahwa indikator pertama yaitu perbandingan antara harapan dan kenyataan pada keseluruhan daya tarik objek wisata yang diterima dipersepsikan paling tinggi oleh wisatawan yaitu dengan rata-rata 3,8, kemudian disusul indikator perbandingan antara harapan dan kenyataan pada semua sarana pendukung yang disediakan, sedangkan indikator ketiga yaitu per- 
bandingan antara harapan dan kenyataan dari perhatian yang diberikan oleh petugas dan penduduk sekitar dipersepsikan paling lemah oleh wisatawan. Hal ini dapat dimaknai bahwa kepuasan wisatawan terhadap daya tarik obyek wisata merupakan faktor utama dalam penentuan tingkat kepuasan wisatawan terhadap DTW yang selanjutnya akan berdampak pada image DTW. Nilai rata-rata keseluruhan indikator pada variabel kepuasan wisatawan sebesar 3,7 dapat diinterpretasikan bahwa wisatawan menilai kepuasan yang dirasakan memiliki kontribusi yang tinggi dalam menentukan image DTW.

\section{Variabel Image}

Pada Tabel 2 tampak bahwa indikator ketiga yaitu kondisi alam berada pada level paling tinggi, disusul indikator iklim dan biaya wisata dipersepsikan paling lemah oleh wisatawan. Hal ini dapat dimaknai bahwa wisatawan memandang kondisi alam DTW yang indah merupakan image utama dari Daerah Tujuan Wisata Malang Raya. Selanjutnya, nilai rata-rata keseluruhan indikator pada variabel image sebesar 4,5 berada dalam kategori tinggi. Sehingga dapat dijelaskan bahwa wisatawan menilai DTWmemiliki image yang kuat.

\section{Pengujian Goodness of Fit Model Pengukuran (Outer Model)}

Pengujian goodness of fit pada outer model untuk setiap variabel yang menggunakan indikator refleksif pada dasarnya adalah pengukuran convergent validity, discriminant validity dan composite reliability. Pada penelitian ini, hanya ada tiga variabel dengan indikator refleksif yaitu motivasi, kepuasan, dan image. Hasil pengujian adalah sebagai berikut:

\section{Convergent Validity}

Pengujian convergent validity diuji dengan melihat nilai outer loading apakah di atas 0,5 atau tidak. Tabel 3 menunjukkan seluruh nilai loading indikator konstruk memiliki nilai di atas 0,5 , meskipun ada satu indikator image yang nilainya di bawah 0,5 akan tetapi cukup dekat nilainya dengan 0,5 , sehingga dapat dijelaskan bahwa pengukuran ini memenuhi persyaratan validitas konvergen.

Tabel 3

Hasil Pengujian Convergent Validity

\begin{tabular}{llcc}
\hline \hline \multicolumn{1}{c}{ Variabel } & \multicolumn{1}{c}{ Indikator } & $\begin{array}{c}\text { Outer } \\
\text { Loading }\end{array}$ & Keterangan \\
\hline \multirow{3}{*}{ Motivasi } & Beristirahat & 0,740 & Valid \\
Wisatawan & Mencari ketenangan & 0,805 & Valid \\
& Kebersamaan dengan keluarga & 0,563 & Valid \\
& Kontak dengan alam & 0,750 & Valid \\
\hline \multirow{2}{*}{ Kepuasan } & Kepuasan terhadap daya tarik wisata & 0,733 & Valid \\
Wisatawan & Kepuasan terhadap sarana pendukung & 0,820 & Valid \\
& Kepuasan terhadap empati & 0,795 & Valid \\
\hline \multirow{2}{*}{ Image DTW } & Iklim & 0,494 & Valid \\
& Biaya murah & 0,599 & Valid \\
& Kondisi alam & 0,964 & Valid \\
\hline
\end{tabular}

Data hasil penelitian, diolah (2011)

\section{Discriminant Validity}

Pengujian discriminant validity menggunakan nilai akar AVE yang dibandingkan dengan korelasi antar variabel laten. Hasil pengujian disajikan pada Tabel 4 berikut: 
Tabel 4

Hasil Pengujian Discriminant Validity

\begin{tabular}{|c|c|c|c|c|c|}
\hline \multirow{2}{*}{ Variabel } & \multirow{2}{*}{ AVE } & \multirow{2}{*}{$\begin{array}{l}\text { Akar } \\
\text { AVE }\end{array}$} & \multicolumn{3}{|c|}{ Skor Korelasi Antar Variabel Laten } \\
\hline & & & Motivasi & Kepuasan & Image \\
\hline Motivasi Wisatawan & 0,519 & 0,720 & & 0,401 & 0,382 \\
\hline Kepuasan Wisatawan & 0,712 & 0,844 & 0,401 & & 0,525 \\
\hline ImageDTW & 0,614 & 0,784 & 0,382 & 0,525 & \\
\hline
\end{tabular}

Data hasil penelitian, diolah (2011)

Hasil pengujian menunjukkan nilai akar AVE (average variance extracted) memperlihatkan nilai yang lebih besar daripada skor korelasi antar variabel latennya, sehingga dapat dinyatakan semua konstruk memenuhi kriteria validitas diskriminan.

\section{Composite Reliability}

Hasil pengujian reliability menggunakan nilai composite reliability untuk variabel motivasi wisatawan, kepuasan wisatawan, image DTW berturut-turut adalah 0,809, 0,881 dan 0,826 . Hasil pengujian menunjukkan bahwa nilai composite reliability lebih besar dari 0,7. Hal ini dapat diinterpretasikan bahwa semua konstruk memenuhi kriteria composite reliability.

Pengujian Goodness of Fit Model Struktural (Inner Model)

Pengujian Goodness of Fit model struktural pada inner model menggunakan nilai predictive-relevance $\left(\mathrm{Q}^{2}\right)$ dan diperoleh menggunakan rumus:

$$
\mathrm{Q}^{2}=1-\left(1-\mathrm{R}_{1}^{2}\right)\left(1-\mathrm{R}_{4}^{2}\right)
$$

Adapun nilai $\mathrm{R}^{2}$ dari masing-masing variabel endogen dalam penelitian ini, berturutturut variabel kepuasan wisatawan dan image DTW, adalah $\mathrm{R}_{1}{ }^{2}=0.374$ dan $\mathrm{R}_{4}{ }^{2}=$ 0.326. Dengan demikian diperoleh nilai predictive-relevance adalah:

$\mathrm{Q}^{2}=1-(1-0,374)(1-0,326)=0,5781=$ $57,81 \%$

Nilai predictive relevance tersebut mengindikasikan bahwa keragaman data yang dapat dijelaskan oleh model tersebut adalah sebesar $57,81 \%$ atau dengan kata lain informasi yang terkandung dalam data $57,81 \%$ dapat dijelaskan oleh model tersebut. Sedangkan sisanya $42.19 \%$ dijelaskan oleh variabel lain (yang belum terkandung dalam model) dan error. Dengan demikian model struktural yang telah terbentuk telah sesuai

Tabel 5

Hasil Pengujian Hipotesis dalam Inner Model

\begin{tabular}{|c|c|c|c|c|c|}
\hline \multirow{2}{*}{$\begin{array}{l}\text { Variabel } \\
\text { Dependent }\end{array}$} & \multirow[t]{2}{*}{ Variabel Independent } & \multicolumn{2}{|c|}{$\begin{array}{l}\text { Koefisien Jalur } \\
\text { Pengaruh } \\
\text { Langsung }\end{array}$} & \multicolumn{2}{|c|}{$\begin{array}{l}\text { Koefisien Jalur Pengaruh } \\
\text { Tidak Langsung }\end{array}$} \\
\hline & & $\begin{array}{l}\text { Std } \\
\text { size }\end{array}$ & t-stat & $\begin{array}{c}\text { Variabel } \\
\text { Moderating }\end{array}$ & $\begin{array}{l}\text { Std } \\
\text { size }\end{array}$ \\
\hline Kepuasan & Motivasi Wisatawan & 0,143 & $2,344^{*}$ & & \\
\hline Wisatawan & Kualitas Layanan & 0,543 & $8,272^{*}$ & & \\
\hline & Kualitas Layanan & 0,280 & $3,894^{*}$ & & \\
\hline Image DTW & $\begin{array}{l}\text { Motivasi dan Kualitas } \\
\text { Layanan }\end{array}$ & 0,358 & $5,334^{*}$ & $\begin{array}{l}\text { Kepuasan } \\
\text { Wisatawan }\end{array}$ & 2,80 \\
\hline
\end{tabular}

Data hasil penelitian, diolah (2011).

Keterangan: tanda * menyatakan signifikan pada taraf $5 \%$ 
Hasil Pengujian Hipotesis Penelitian

Hasil pengujian hipotesis penelitian dalam inner model (structural model) tercantum dalam Tabel 5. Hasil pengujian hipotesis tersebut secara lengkap digambarkan dalam bentuk jalur-jalur sebagaimana dapat dilihat pada Gambar 2.

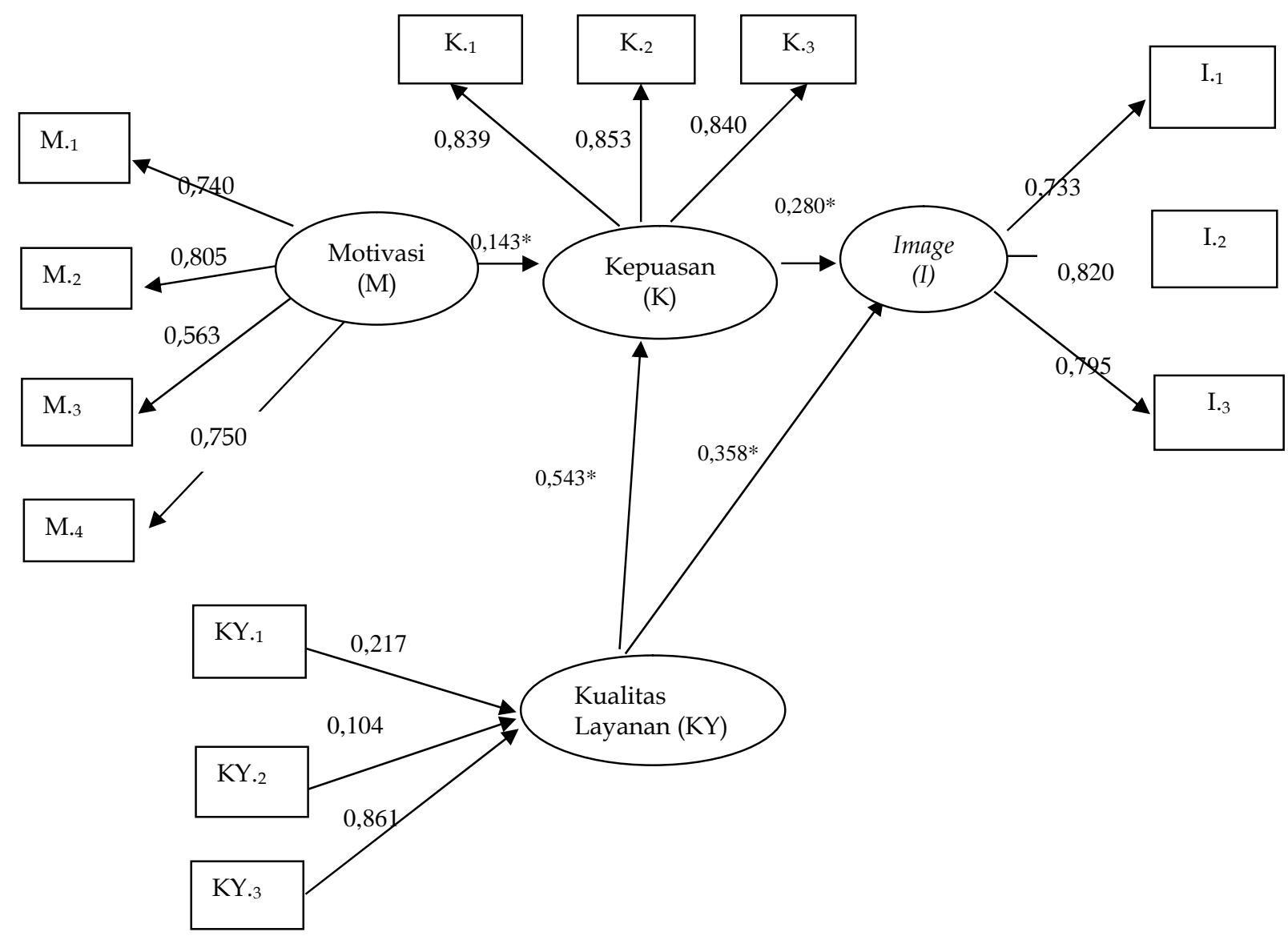

Gambar 2

Diagram Jalur Hasil Pengujian Hipotesis Inner Model

Berdasarkan Gambar 2, dapat dijelaskan bahwa terdapat bukti empiris untuk menerima semua hipotesis yang mana hubungan antar variabel yang diuji berpengaruh positif, baik secara langsung maupun tidak langsung.

\section{PEMBAHASAN}

Pengaruh Motivasi Wisatawan terhadap Kepuasan Wisatawan

Dari hasil penelitian pada Tabel 5 memperlihatkan bahwa adanya pengaruh positif antara motivasi wisatawan terhadap kepuasan wisatawan. Hal ini dapat dimaknai bahwa semakin tinggi motivasi wisatawan untuk relaksasi, mencari ketenangan, kebersamaan dengan keluarga dan kontak dengan alam, maka akan semakin tinggi pula kepuasan yang dirasakan wisatawan terhadap kualitas layanan yang diterima pada daerah tujuan wisata. Temuan penelitian ini sejalan dengan kajian yang dilakukan oleh Devesaet al. (2010) di Spanyol, Penelitian yang bertujuan menginvestigasi hubungan antara motivasi dan kepuasan wisatawan, mengungkapkan bahwa motivasi berpengaruh pada kepuasan wisatawan.

Sementara itu, temuan penelitian ini bertentangan dengan temuan dari kajian Yoon dan Uysal (2005). Dimana penelitiannya mengungkapkan bahwa motivasi ber- 
pengaruh tidak signifikan pada kepuasan wisatawan. Perbedaan temuan dari kedua penelitian tersebut dapat bersumber dari beberapa hal, diantaranya indikator sebagai parameter yang digunakan, alat analisis data dan objek kajian yang berbeda. Seperti pada penelitian Devesa et al. (2010) motivasi wisatawan dikelompokan ke dalam empat cluster, yaitu 1)Visitor looking for tranquillity, rest and contact with nature, 2. Cultural visitor 3) Priximity, gastronomic and nature visitor 4). Return tourist. Dengan menggunakan ANOVA, faktor dan cluster sebagai alat analisis. Sementara itu, Yoon dan Uysal (2005) menggunakan exciting, education, relaxation, achievement, family togetherness, escape, safety/ fun dan away from home and seeing sebagai parameter motivasi wisatawan. Objek penelitiannya adalah wisatawan yang tinggal di hotel pada Northern Cyprus-Mediterrania, dan dianalisis dengan Structural Equation Modelling (SEM).

Dari uraian tersebut di atas dapat dimaknai bahwa motivasi wisatawan mengunjungi DTW dapat berpengaruh atau tidak berpengaruh positif pada kepuasan yang dirasakan wisatawan terhadap DTW. Dengan demikian, hal ini dapat dijadikan bahan masukan bagi pengelola dan pemerintah terkait dalam merancang strategi pengelolaan sebuah DTW. Terkait dengan hasil penelitian ini yang menyatakan bahwa motivasi wisatawan berpengaruh positif pada tingkat kepuasan wisatawan, maka ke depan pengelolaan DTW harus selalu menjaga kondisi objek-objek wisata yang ditawarkan agar dapat memenuhi kebutuhan wisatawan selama berwisata di DTW. Beberapa strategi yang dapat dilakukan adalah tetap membuat DTW dan sekitarnya menjadi daerah yang aman, seperti aman dari teror, keributan, demonstrasi dan sebagainya.

Selanjutnya, membuat situasi dan kondisi di DTW khususnya di tempat objekobjek wisata sebagai tempat yang nyaman untuk berinteraksi dengan keluarga serta alamnya yang tetap terjaga dengan baik.

\section{Pengaruh Kualitas Layanan terhadap Kepuasan Wisatawan}

Dari hasil pengujian hipotesis pada Tabel 5 memperlihatkan bahwa adanya pengaruh positif antara kualitas layanan terhadap kepuasan wisatawan, ini dapat dimaknai semakin tinggi kualitas layanan yang ditunjukkan dengan daya tarik objek wisata, kondisi sarana pendukung dan empati masyarakat sekitar kepada wisatawan, maka akan semakin tinggi pula kepuasan yang dirasakan wisatawan. Temuan penelitian ini mendukung teori service menurut Kotler dan Keller (2012) yang menjelaskan bahwa apabila kualitas layanan yang dirasakan melampaui harapan wisatawan, berarti jasa tersebut telah memberikan suatu kualitas yang luar biasa dan juga akan menimbulkan kepuasan yang sangat tinggi (very satisfy). Sebaliknya, apabila harapannya itu tidak tercapai, maka diartikan kualitas jasa tersebut tidak memenuhi apa yang diinginkannya atau perusahaan tersebut gagal melayani wisatawannya. Apabila harapannya sama dengan apa yang di peroleh, berarti wisatawan itu puas (satisfy). Secara empiris, temuan penelitian ini sejalan dengan hasil penelitian Ibrahim dan Gill (2005), Andaleeb dan Conway (2006), Kandampully dan $\mathrm{Hu}$ (2007), Martaleni (2011) yang menjelaskan bahwa kualitas layanan berpengaruh signifikan terhadap kepuasan wisatawan. Di sisi lain hasil penelitian ini bertentangan dengan temuan penelitian, Coreria dan Valle (2007).

Hutcinson, et al. (2009) yang mengatakan bahwa kualitas layanan tidak berpengaruh signifikan terhadap kepuasan wisatawan. Perbedaan temuan penelitian tersebut, dapat disebabkan oleh banyak hal, diantaranya: perbedaan tempat penelitian, karakteristik responden, populasi dan jumlah sampel yang digunakan dan sebagainya. Coreria dan Valle (2007) melakukan penelitian tentang "Why people travel to exotic places" dengan populasi wisatawan Portugis. Dari hasil analisisnya menjelaskan bahwa wisatawan Portugis tidak puas terhadap kualitas layanan yang ditawarkan, karena 
wisatawan yang datang ke tempat wisata tidak hanya bermotivasi untuk berwisata tapi juga untuk memecahkan konflik yang dirasakan. Bila wisatawan datang ke tempat wisata untuk memecahkan konflik, kemungkinan kualitas layanan yang diberikan tidak menjadi harapannya.

Dari temuan penelitian tersebut, dapat dimaknai bahwa peningkatan kualitas layanan yang diberikan pada DTW tidak serta merta dapat meningkatkan kepuasan wisatawan, namun, dalam penelitian ini diungkapkan bahwa peningkatan kualitas layanan memberikan dampak positif bagi kepuasan wisatawan. Hal ini dapat dijadikan sebagai bahan masukan oleh pengelola objek wisata dan pemerintah terkait dalam perencanaan tentang kualitas layanan. Peningkatan kualitas layanan wisata merupakan keharusan yang tidak dapat diabaikan, mengingat kebutuhan dan keinginan wisatawan yang terus berubah dan bervariasi akan produk wisata. Beberapa bentuk peningkatan kualitas layanan wisata yang dapat dilakukan adalah: penambahan objek-objek wisata yang lebih menarik bagi keluarga, akses transportasi yang semakin mudah dan lancar, fasilitas umun yang nyaman dan bersih serta peningkatan empati petugas melalui pelayanan yang lebih ramah, dan lebih komunikatif.

\section{Pengaruh Kualitas Layanan Terhadap Image}

Dari hasil penelitian pada Tabel 5 memperlihatkan bahwa adanya pengaruh positif antara kualitas layanan terhadap image. Artinya semakin tinggi kualitas layanan wisata yang diwujudkan dengan daya tarik objek wisata, sarana pendukung dan empati, maka akan semakin tinggi pula image wisatawan terhadap DTW Malang Raya sebagai daerah tujuan wisata yang memiliki iklim yang sejuk, berbiaya murah dan sebagai daerah tujuan wisata alam.

Temuan penelitian ini mendukung teori dari Kotler dan Kelller (2012) yang menjelaskan bahwa image merupakan bagian penting dalam menilai kualitas jasa.
Apabila dalam pikiran wisatawan sudah tertanam kesan yang positif kepada perusahaan jasa tertentu, meskipun terjadi beberapa kesalahan dalam penyampaian jasa, maka kekurangan ini dapat ditutup oleh image positif ini. Hasil kajian empiris ini mendukung temuan dari Kandampully dan Hsin-Hui Hu (2007); Martaleni (2011) dimana temuannya mengungkapkan bahwa kualitas layanan wisata berpengaruh signifikan pada image.

Penjelasan ini memberikan pemahaman bahwa agar image daerah tujuan wisata Malang Raya selalu positif, maka pihak yang berwenang di Malang Raya harus selalu meningkatkan kualitas layanan dari daya tarik obyek wisata yang ditawarkan pada wisatawan. Mempertahankan dan meningkatkan kualitas layanan yang dapat dilakukan melalui pembenahan obyekobyek wisata yang ada, meningkatkan skill sumberdaya manusia, dan memberikan edukasi pada masyarakat sekitar akan arti pentingnya memberikan perhatian pada wisatawan. Temuan penelitian ini sejalan dengan penelitian yang telah dilakukan oleh Hankinson (2005) dan Kandampully, Hsin-Hui Hu (2007) masing-masing melakukan penelitian di daerah tujuan wisata UK dan Hotel di Mouritius. Kedua penelitian tersebut dapat mengungkapkan bahwa, semakin meningkat kualitas layanan yang diberikan oleh daerah tujuan wisata dan hotel akan semakin meningkatkan image wisatawan terhadap daerah tujuan wisata dan hotel. Temuan ini dapat dimaknai bahwa penelitian yang dilakukan pada objek kajian dan daerah yang berbeda, dapat menghasilkan temuan yang sama.

\section{Pengaruh Motivasi Wisatawan dan Kuali- tas Layanan terhadap Image melalui Kepuasan}

Dari hasil penelitian memperlihatkan bahwa adanya pengaruh positif secara tidak langsung antara motivasi wisatawan dan kualitas layanan terhadap image melalui kepuasan. Hal ini memberikan makna bahwa semakin tinggi motivasi wisatawan 
untuk berwisata dan tingginya nilai kualitas layanan wisata akan dapat meningkatkan image daerah tujuan wisata dengan terlebih dulu wisatawan merasa puas terhadap DTW.

Temuan ini sejalan dengan hasil penelitian Kandampully dan Hsin-Hui $\mathrm{Hu}$ (2007), Chi dan Qu (2008) yang menjelaskan bahwa kepuasan wisatawan berpengaruh signifikan dengan image. Demikian juga dalam temuan penelitian Kandampully dan Hsin-Hui Hu, 2007; Chen dan Tsai, 2007; Chi dan Qu, 2008; Brunner. Stocklin, dan Opwis, 2008; Park, D-Y dan Yoon, Y-S, 2009; Chen dan Chen, 2010) menjelaskan bahwa kepuasan pelanggan secara signifikan mempengaruhi citra (image). Ini dapat diartikan bahwa penelitian yang dilakukan pada obyek dan lokasi yang berbeda dapat berlaku juga pada penelitian ini, yang memilih daerah tujuan wisata sebagai obyek kajiannya. Pemenuhan kepuasan wisatawan merupakan faktor penting yang secara tidak langsung dapat meningkatkan image DTW Malang Raya.

Kepuasan wisatawan pada daerah tujuan wisata Malang Raya dapat terpenuhi bila kenyataan yang mereka rasakan akan adanya daya tarik obyek wisata, sarana pendukung yang memadai, petugas yang ramah dan penduduk yang bersahabat sesuai dengan harapan. Daya tarik obyek wisata yang ditawarkan harus benar-benar bervariasi sesuai kebutuhan wisatawan. Sebagai contoh adanya wisata rekreasi yang menarik dan nyaman, wisata belanja dengan keragaman produk yang berkualitas, pelayanan dengan penuh keramahan dan harga yang terjangkau serta keindahan alam yang tetap terjaga.

\section{SIMPULAN DAN SARAN Simpulan}

Berdasarkan pembahasan yang dijelaskan sebelumnya, maka dapat ditarik beberapa simpulan sebagai berikut. Pertama, semakin tinggi motivasi wisatawan untuk beristirahat (relaksasi) bersama keluarga dalam rangka mencari ketenangan/ke- heningan di tempat yang dapat langsung kontak dengan alam, akan semakin mempertinggi kepuasan wisatawan terhadap DTW Malang Raya. Kedua, semakin menarik obyek wisata dengan dilengkapi sarana pendukung yang baik disertai dengan keramahan dan empati petugas dan penduduk terhadap wisatawan, semakin mempertinggi kepuasan wisatawan. Keadaan ini secara langsung dapat memperkuat image DTW Malang Raya. Ketiga, semakin tinggi motivasi wisatawan dan kualitas layanan wisata secara tidak langsung melalui kepuasan wisatawan dapat memperkuat image DTW Malang Raya sebagai DTW yang memiliki iklim sejuk, berbiaya murah dan kondisi alam yang indah.

\section{Saran}

Kajian image DTW akan lebih lengkap apabila melibatkan semua wisatawan, yaitu wisatawan nusantara, wisatawan bisnis serta wisatawan mancanegara. Sementara itu dalam peneitian ini hanya melibatkan wisatawan nusantara. Oleh karena itu untuk penelitian berikutnya disarankan untuk melakukan kajian dengan melibatkan wisatawan bisnis dan mancanegara sehingga akan diperoleh informasi yang lebih dalam dan menyeluruh tentang image DTW Malang Raya.

\section{DAFTAR PUSTAKA}

Andaleeb, S. S dan Conway. 2006. Customer Satisfaction in The Restaurant Industry: An Examination of The TransactionSpecific Model. Journal or Service Marketing 20(1): 3-11.

Anonim, 2014. Tourism Highlights. World Tourism Organization UNWTO

Anonim. 2012. Rencana Strategis (RENSTRA) Direktorat Pengembangan Destinasi Wisata 2012-2014, Kementerian Pariwisata Kreatif.

Brunner, T. Stocklin, M dan Opwis, K. 2008. Satisfaction, Image, and Loyalty: New Versus Experienced Customers. European Journal of Marketing 42(9): 10951105. 
Chen, C. F dan F-S Chen. 2010. Experience Quality, Perceived Value, Satisfaction and Behavirol Intentions For Heritage Tourists. Tourism Management 31(1): 2935.

Chen, C. F dan D. C. Tsai. 2007. How Destination Image and Evaluation Factors affect Behavioral Intentions. Tourism Managemen (28): 1115-1122.

Chi, C, G. G dan Qu, Hailin. 2008. Examining The Structural Relationships Of Destination Image, Tourist Satisfaction and Loyalty: An integrated approach. Tourism Management 29(4): 624-636.

Correia, A dan P. O. D. Valle. 2007. Why People Travel to Exotic Places. International Journal of Culture 1(1): 4561.

Devesa, M., M Laguna dan A. Palacios. 2010. The Role Motivation In Visitor Satisfaction: Empirical Evidence In Rural. Tourist. Tourism Management 31(4): 557-542.

Fandeli, C. 2008. Mengembangkan Pariwisata Berbasis Masyarakat, Pusat Studi Pariwisata Universitas Gajah Mada.

Faullant, R., K. Matzler dan J. Fuller. 2008. The Impact of Satisfaction and Image on Loyalty: The Case of Alpine Ski Resorts. Managing Service Quality 18(2): 163-178.

Hankinson, G. 2005. Destination Brand Image A Business Tourism Perspective. Journal Of Service Marketing 19(1): 24-32.

Hutchinson, J., F. Lay dan Y. Wang. 2009. Understanding The Relationships Of Quality Value, Equity, Satisfaction, And Behavioral Intentions Among Golf Travelers. Tourist Management 30(2): 298-308.

Ibrahim, E.E dan J. Gill. 2005. A Positioning Strategy for a Tourism Destination, Based on Analysis of Customers Perception and Satisfactions. Marketing Intelegence and Planning 23(2): 172-188 .

Kandampully dan H. H. Hu. 2007. Do Hoteliers Need To Manage Image To Retain Loyal Customer? International
Journal Of Contemporary Hospitality Management 19(6): 435 - 443

Kotler, P dan K. L Keller. 2012. Marketing Management, 14 nd Pearson Education, Inc, New Jersey.

Labato, L. H dan M. M. S. Radila. 2006. Tourism Destination Image, satisfaction and Loyalty: A study in Ixtapa-Zihuantanego. Tourism Geographies 8(4): 343358.

Lamb, C. W., J. F Hair dan C. Mc Daniel. 2005. Pemasaran, PT. Salemba Empat, Jakarta.

Martaleni. 2010a. Arti dan Pengukurann Image Daerah Tujuan Wisata. Jurnal Manajemen Gajayana (JMG) 7(1): 49-56.

$.2010 \mathrm{~b}$. Pengembangan Pariwisata sebagai Pemberdayaan Ekonomi Masyarakat, Prosiding Seminar Nasional Kewirausahaan I, UB-Malang, 263-271

.2011. Image Daerah Tujuan Wisata: Suatu Tinjauan Dari Perspektif Wisatawan Nusantara. EKUITAS, Jurnal Ekonomi dan Keuangan 15(4): 501522.

Mohammad, B. A. M, dan A. P. M. Som. 2010. An Analysis Push and Pull Travel Motivation of Foreign Tourists to Jordan. International Journal of Business and Management 5(12): 41-50.

Park, D. B dan Y. S. Yoon. 2009. Segmentation by Motivation in Rural Tourism: A Korean Case Study. Tourism Management 30(1): 99-108.

Pitana, I. G dan I. K. S. Diarta. 2009. Pengantar Ilmu Pariwisata. Andi Ofset, Yogyakarta

Solimun, 2008. Memahami Metode Kuantitatif Mutakhir: Structural Equation Modeling and Partial Least Square, Program Studi Statistika FMIPA Universitas Brawijaya, Malang.

Tjiptono, F dan G. Chandra. 2011. Service, Quality and Satisfaction. Andi. Yogyakarta.

Tsung, H. L. 2009. A Structural Model for Examing How Destination Image and Interpretation Services Affect Future Visitation Behavior: a case study of 
Taiwan's Taomi eco-village. Journal of Sustainable Tourism 17(6): 727-745.

Vellas, F dan L. Becherel. 2008. Pemasaran Pariwisata International Sebuah Pendekatan Strategis. Yayasan Obor Indonesia.

$\mathrm{Wu}, \mathrm{C} . \mathrm{H}, \mathrm{J} .2007$. The Impact of customerto-customer Interaction and Customer Homogenity on Customer Satisfaction in Tourism service-the service Enconter Prospective, Tourism Management 289(6): 1518-1528.

Yoeti, H. O. A. 2006. Tours and Travel Marketing, PT. Pradnya Paramita, Jakarta
Yoon, Y dan M. Uysal. 2005. An Examinatin of the Effects of Motivation and satisfaction on Destination Loyaty: a Structural Model. Tourist Management 26(1): 45-56.

Yuksel, A. Yuksel, F dan Y. Bilim. 2010. Destination attachment: Effects on Customer Satisfaction and Cognitive an Conative loyalty. Tourism Management 31(2): 274-284. 